\title{
EFFECT OF ORGANIZATIONAL CULTURE ON CUSTOMER SATISFACTION AMONG HOSPITALITY INDUSTRY OPERATED BY RELIGIOUS CONGREGATIONS IN KAREN, NAIROBI-KENYA
}

\author{
Sawadogo Georgette Sidbewendin ${ }^{1}$, Dr. Aloys Ojore ${ }^{2}$ and Dr. Joyzy Pius Egunjobi ${ }^{3}$ \\ ${ }^{1,2}$ Institute of Social Transformation, Tangaza University College, The Catholic University of Eastern \\ Africa Nairobi, P.O. Box 15055-00509 Langata, Nairobi-Kenya \\ ${ }^{3}$ Psycho-Spiritual Institute, Marist International University College Nairobi, P.O. Box 24450-00502 \\ Karen, Nairobi-Kenya
}

DOI: 10.46609/IJSSER.2020.v05i11.003 URL: https://doi.org/10.46609/IJSSER.2020.v05i11.003

\begin{abstract}
The purpose of the study was to examine the effect of organizational culture on customer satisfaction in hospitality industry run by religious congregations. The study was anchored on the Competing Values Framework theory. It adopted a correlational design and used purposive sampling technique to select 248 participants. Data were collected using Competing Values Assessment Instrument with reliability coefficient of .671, .720, .682, and .691 for clan culture, adhocracy, hierarchy, and market culture respectively and Customer Satisfaction Questionnaire with a reliability coefficient of .815 . Data were analyzed using One sample t-test and Chi-square analysis. The results indicated that organizational culture was strongly related to customer satisfaction. Again, customer satisfaction was highest in the congregation who has hospitality as their charism. In the same vein, clan and adhocracy culture which promote collaboration and innovation among staff enhances customer satisfaction. The outcome of this study is useful to hospitality Centre operated by religious congregations and other organizations to identify their dominant and preferred organizational culture types and how to use this to enhance their overall performance.
\end{abstract}

Key Words: Hospitality, clan, adhocracy, hierarchy, market culture, customer and satisfaction

\section{INTRODUCTION AND BACKGROUND}

The importance of the hospitality sector cannot be over emphasized considering its tremendous contributions in enhancing economic growth and development of various countries through employment generation and improvement of the Gross Domestic Product (GDP) (Rosa \& 


\section{International Journal of Social Science and Economic Research}

ISSN: $2455-8834$

Volume:05, Issue:11 "November 2020"

Hastings, 2016). Hospitality industry comprises front office, accommodation, food, and drinks in venues different from a person's home. This industry makes both direct and indirect impact on the economy of every nation. Directly it creates employment, while it indirectly leads to more employment in the marketing industry, farming, and supply and delivery industry. It is believed that the growth of tourism goes hand in hand with hospitality.

On the global scene, tourism and hospitality contributes significantly to various economies with improvements recorded in countries such as: South Africa, Kenya, Hong Kong, and the Caribbean (Adeola \& Ezenwafor, 2016). For example, tourism and hospitality industry contributed about USD 1.3 trillion dollars to the world economy in 2012 alone. It was also estimated that payment for hospitality services accounted for about 70 to 75 percent of annual expenses of tourists (Babalola \& Oluwatoyin, 2014). These studies revealed that hospitality serves as key player in employment as well as income generation in most countries when enabling environment is created for the hospitality industry. Moreover, it indicates the importance of customer satisfaction who are the direct consumers of the goods and services of the industry.

In 2017, the travel and tourism sector in the United States (US) accounted for a revenue of over 1.6 trillion dollars, providing jobs for 7.8 million employees, and representing 2.8 percent of GDP. Out of this, hospitality industry through accommodation and food services generated about 554 billion dollars and supported about 4.2 million jobs. It is reported that income from tourism in the United States of America for 2017 was 251 billion dollars resulting in a trade surplus of 77 billion dollars (Select USA, 2019). The impact of hospitality industry to the economy cannot be ignored.

In Europe, the hospitality industry is also a major influence on the economy by way of employment, tax revenue, and growth. According to Christian (2015) hospitality in Europe provide direct jobs for 10.2 million people, with revenue of over 1.0 trillion Euros, representing approximately 8.1 percent of the total economic output, which represents about 3.7 percent of GDP. Hospitality industry employed about 16.6 million workers which represents 7.8 percent of the workforce of Europe. This indicated that in Europe, one in every thirteen jobs is created by hospitality industry. This indicates that hospitality contributes a lot to individual economies of the European Union. Hence it sounds to reason to say that customer satisfaction is central in hospitality industry as this determine both continuous patronage and the overall performance.

Hospitality industry is reported as one of the industries with a rapid growth rate in China. This rapid development has seen tremendous increment in the number of hotels and hotel rooms over the past 15 years. For example, hotels and hotel rooms in China increased from 522 hotels and 
International Journal of Social Science and Economic Research

ISSN: 2455-8834

Volume:05, Issue:11 "November 2020"

56,854 hotel rooms in 2001 , to 21,481 hotels and 1, 969,145 hotel rooms as at January 1,

2016 (Lianping, 2019). In 2016, hospitality industry in China recorded 138 million overseas visitors and revenue of $\$ 120$ billion which is a 3.8 percent increase from that of 2015 (Lianping, 2019). This observed growth in general performance attest to the industry's huge capacity to contribute to economic growth through quality service delivery and customer satisfaction in China and beyond.

In Africa, the scenario is not different as hospitality business constitutes a vital factor in the economy of the different countries. For example, in 2016, hospitality and tourism in South Africa contributed R402 billion to the economy, which represents 9.3 percent of the GDP and supports about 1.5 million jobs in 2016 which represents 9.8 percent of the overall employment in South Africa (WTTC, 2017). Also, tourism and hospitality industry contributed 5.7 percent of the total GDP, and 5.1 percent of the total employment of Egypt (Radwan \& Radwan, 2017). Again, in 2018, travel and tourism contributed 8 billion US dollars to the GDP of Kenya, representing an average annual growth rate of 8.49 from 2.3 billion dollars in 1999 (KNBS, 2018). A further analysis of tourism and hospitality in Kenya between 2013 and 2018 indicated that about 60 percent of employment in the tourism industry in Kenya falls into the food, beverage and sales, and accommodation (Government of Kenya, 2013). This was again supported by Ondieki and Kung'u (2013) who indicated that hospitality industry in Kenya provide jobs for about 10 percent of the overall employees in the country, majority of whom $(64 \%)$ are unskilled and semi-skilled employees. The economic importance of hospitality industry necessarily leads to the issue of customer and customer satisfaction in hospitality industry.

A customer or client is a recipient of goods or services, an idea or a product from a marketer, trader, merchant, or provider through the dynamics of monetary transaction or some other valuables (Kendall, 2007). Again, a customer is a person who makes use of the paid products through purchasing or renting goods or services. This understanding is directly connected to the issue of customer satisfaction in business transactions. The importance of the satisfaction of customer lies in its relatedness to customer loyalty; repurchase intention of customers, and the overall performance of organizations (Dikmen, 2017). Customer satisfaction therefore, is the ultimate criterion for assessing an organization's success because it is the customers who pay for the goods and services offered by such organizations. This is true of a very competitive business like the hospitality industry. It means that, when the customers are satisfied with the quality of services received in a particular hospitality industry, their loyalty (continuous patronage), will be retained, and the performance of the industry enhanced. 


\section{International Journal of Social Science and Economic Research}

ISSN: $2455-8834$

Volume:05, Issue:11 "November 2020"

Dikmen (2017), describes customer satisfaction as the deserved outcome of hospitality industry. But the ability to satisfy the customer is related to the operating culture in such hospitality industry. Organization's culture shapes the behaviour of employees (how they think, work and feel) which leads to customer satisfaction. It is formed by the leaders of an organization in responses to the need for adaptation and survival in the competitive external environment. Similarly, organizational culture at some point can be effective while at other times it can become ineffective. Thus, when such organizations are not innovative, this can lead to the inability to achieve the goals of an organization due to dysfunctionality of organizational culture (Kamau \& Wanyoike, 2018; Sharma, \& Singh, 2017). This understanding raised interest in the study of how the culture of an organization influences customer satisfaction.

Studies on management science have established that the culture of an organization has strong influence on the overall performance of hospitality industry (Mensah \& Mensah, 2018; Kruja, Ha, Drishti, \& Oelfke, 2016). Other studies indicated that, organization culture has strong impact on performance of different organizations (Ekpenyong and Ekpenyong, 2016; Okan \& Okan, 2014). Lastly, others identified specifically that organization culture has positive impact on customer satisfaction (Al-Otaib, Yusof, \& Wanlsmail, 2019; Dikmen, 2017), growth or profitability of organization, and employee development (Kamau \& Wanyoike, 2018; Owino \& Kibera, 2019). The presence of religious congregations in the hospitality industry poses the need to explore how their unique charism informs their organizational culture and the customer satisfaction in their hospitality Centre. However, the reviewed studies have not explored organizational culture and customer satisfaction in hospitality industry among religious congregations.

Moreover, the positive impact of hospitality industry on economy alludes to the importance of the culture of an organization on its performance in hospitality industry. Different organization culture type promotes organization performance through customer satisfaction and customer loyalty (Dikmen, 2017; Irfan, Shamsudin, \& Hadi, 2016). This means that, whether the investor(s) in hospitality organization is government, corporate body, individual personal investment, or religious congregation, understanding its organization culture and how it influences customer satisfaction, and performance is very important. For example, a study showed that the best indicator of innovation and performance among Spanish companies was adhocracy culture (Naranjo, Jimenez, \& Sanz, 2015). Similarly, Clan and Hierarchical forms of organizational culture have strong positive influence on non-market achievement or performance of Micro-Finance banks in Kenya (Owino \& Kibera, 2019). These studies show that organizational culture has strong effect on the achievement of different industries because organizational culture encapsulates the vision, and goals of such organizations and how to achieve its objectives. Thus, within the religious congregations managing hospitality industry, 


\section{International Journal of Social Science and Economic Research}

ISSN: $2455-8834$

Volume:05, Issue:11 "November 2020"

this could become a means for social transformation for the less privilege through customer satisfaction.

Studies on how the culture of an organization influence the satisfaction of customers have been conducted in many and diverse organizations (Dikmen, 2017; Malik \& Ghaffor, 2012; Gronoos, 2007) with plausible results. Customer satisfaction is the path which leads to customer retention, but unsatisfied customers switch patronage at a high rate (Lin \& Wu, 2011). Also, customers' satisfaction is related to service quality which has ripple effects on customers' loyalty, and perceived value and customers' loyalty (Irfan, Shamsudin, \& Hadi, 2016). Similarly, Mensah and Mensah (2018) established that indicators of organizational culture such as responsivenessassurance, empathy-equity, reliability and tangibles, had significant effect on customers' satisfaction and the intention to repurchase.

However, studies on hospitality industry seem not to focus much on the organizational culture in the hospitality industry as a means for customer satisfaction. Moreover, there is scarcity of literature on hospitality industry that is run by the religious congregations, and how such hospitality industry rates in terms of customer satisfaction. This study therefore explored the effect of organizational culture on customer satisfaction in hospitality centre run by religious congregations in Karen, Nairobi-Kenya.

Research Hypothesis: Organizational culture has no statistically significant effect on customer satisfaction among hospitality industry in religious congregations in Karen, Nairobi - Kenya.

\section{METHODS}

This research was conducted in Karen, a suburb situated in the south-west of Nairobi central business district. Three religious congregations were selected because they operate hospitality industry. The study adopted a correlation design. Target population for the study was estimated to be about 650 persons from the three selected religious congregations. A sample size of 248 participants was selected using Yamane (1973) sample size formula. Purposive sampling technique was used to select the participants for the study.

This study used Competing Values Assessment Instrument (CVAI), with a Cronbach's alpha coefficient of .671,.720, .682, and .691 for clan culture, adhocracy, hierarchy, and market culture respectively and the Customer Satisfaction Scale with a Cronbach's alpha coefficient of .815. This indicated that the research instruments had a very good reliability.

Data Collection Procedures: The researcher obtained research permit the National Commission for Science, Technology and Innovation (NACOSTI), and the directors of the selected hospitality 
Centre. Thereafter, the service of a male research assistant was employed to help the researcher in the process of data collection. In the three congregations, the researcher and the research assistant worked with the directors to administer the questionnaires to the staff on site, and the guests online during the COVID-19 lockdown.

Data Analysis and Presentation: Data from 201 participants were analysed using the statistical package for the social sciences (SPSS) version 22. The study hypothesis was tested using One sample t-test and Chi square analysis to establish the effect of organizational culture on customer satisfaction among hospitality industry in religious congregation in Karen, Nairobi.

\section{RESULTS}

\section{Demographic Information}

The demographic characteristics of the participants were examined to give a clear understanding of the composition of the population used in the current study. This again was to provide basis for comparative analysis in this and other studies. The demographic characteristics of the staff are presented in figures while demographic profile of customer participants is presented in Table 1 .

\section{Table 1}

Demographic Characteristics of the Participants $(N=201)$

\begin{tabular}{lcccc}
\hline Categories & \multicolumn{2}{c}{ Staff } & \multicolumn{2}{c}{ Customer } \\
\hline Congregation & Frequency & Percent & Frequency & Percent \\
\hline Congregation 1 & 17 & 39.5 & 77 & 48.7 \\
Congregation 2 & 16 & 37.2 & 37 & 23.5 \\
Congregation 3 & 10 & 23.3 & 44 & 27.8 \\
Total & $\mathbf{4 3}$ & $\mathbf{1 0 0}$ & $\mathbf{1 5 8}$ & $\mathbf{1 0 0}$ \\
Gender & & & & \\
Male & 16 & 37.2 & 86 & 54.4 \\
Female & 27 & 62.8 & 72 & 45.6 \\
Total & $\mathbf{4 3}$ & $\mathbf{1 0 0}$ & $\mathbf{1 5 8}$ & $\mathbf{1 0 0}$ \\
Education & & & & \\
Secondary School & 7 & 16.3 & 30 & 19 \\
Diploma & 12 & 27.9 & 63 & 39.9 \\
BA & 11 & 25.6 & 44 & 27.8 \\
MA & 10 & 23.3 & 7 & 4.4 \\
PhD & 1 & 2.3 & 14 & 8.9 \\
Others & 2 & 4.7 & & \\
& & & & \\
\end{tabular}


International Journal of Social Science and Economic Research

ISSN: $2455-8834$

Volume:05, Issue:11 "November 2020"

\begin{tabular}{|c|c|c|c|c|c|}
\hline Total & 43 & 100 & & 158 & 100 \\
\hline Charism in Hospitality & & & Religion & & \\
\hline Yes & 17 & 39.5 & Christianity & 155 & 98.1 \\
\hline No & 26 & 60.5 & Islam & 1 & .6 \\
\hline \multirow[t]{8}{*}{ Total } & 43 & 100 & Others & 2 & 1.3 \\
\hline & & & & 158 & 100 \\
\hline & & \multicolumn{4}{|c|}{ Marital Status } \\
\hline & & & Married & 29 & 18.4 \\
\hline & & & Single & 2 & 1.3 \\
\hline & & & Parent & & \\
\hline & & & Single & 127 & 80.3 \\
\hline & & & Total & 158 & 100 \\
\hline
\end{tabular}

The results from Table 1 on the staff participants indicated that congregation 1 represents 17 (39.5\%) participants, followed by congregation 2 with 16 (37.2\%) participants, and congregation 3 with $10(23.3 \%)$ participants. This means that congregation 1 had the highest staff participants in this study followed by congregation 2 and 3 respectively. Also, the results showed that male religious represents $16(37.21 \%)$ of the participants, while female religious represented 27 $(62.79 \%)$ of the staff participants in the current study. This means that, the current study had more female religious staff than male religious staff. Further, 17 (39.53\%) of the participants indicated that hospitality is a charism in their congregation. But majority $(60.47 \%)$ of the participants indicated that hospitality was not their charism. This means that, only one congregation in the current study had hospitality as their charism. Moreover, in terms of educational attainment, 12 (27.9\%) of the staff had Diploma, 11(25.6\%) Bachelor, 10 (23.3\%) of the staff had Master degree, and only a single staff had $\mathrm{PhD}$ degree. This means that, most of the participants $(51.2 \%)$ in the current study had at least a bachelor degree. This again indicated that 48.8 had diploma degree and below.

The results from Table 1 again indicated that most of the customer participants (48.7\%) were from Congregation one, while Congregation two and three accounted for $52.5 \%$ of the customers in the current study. In terms of the gender of the participants, the male participants (54.4\%) were more than female participants $(45.6 \%)$. The results further show that majority of the participants $(67.7 \%)$ had at least BA degree. This means that most of the participants in the current study were educated enough to understand and answer the questionnaire correctly. Majority (80.3\%) of the participants were single while only $19.7 \%$ were either married or single parents. Similarly, majority of the participants $(98.1 \%)$ were Christians. The findings may not be unconnected with the fact that these hospitality industries are operated by religious congregations. Hence most of the customers were Christians and religious men and women.

The objective of this study was to investigate the effect of organizational culture on customer 
satisfaction among hospitality industry in religious congregations in Karen, Nairobi. Hence, the participants were given self-reported Competing Value Assessment Instrument (CVAI) and Customer Satisfaction Scale, to identify the organizational culture in the congregations and establish if it had any significant effect on the satisfaction of customers in hospitality industry operated by religious congregations. The results from the One sample t-test and Chi-square analysis are presented in Figure 1 and Table 2.

\section{Figure 1}

One Sample Test Mean Plot of the Organizational Culture among the Participants

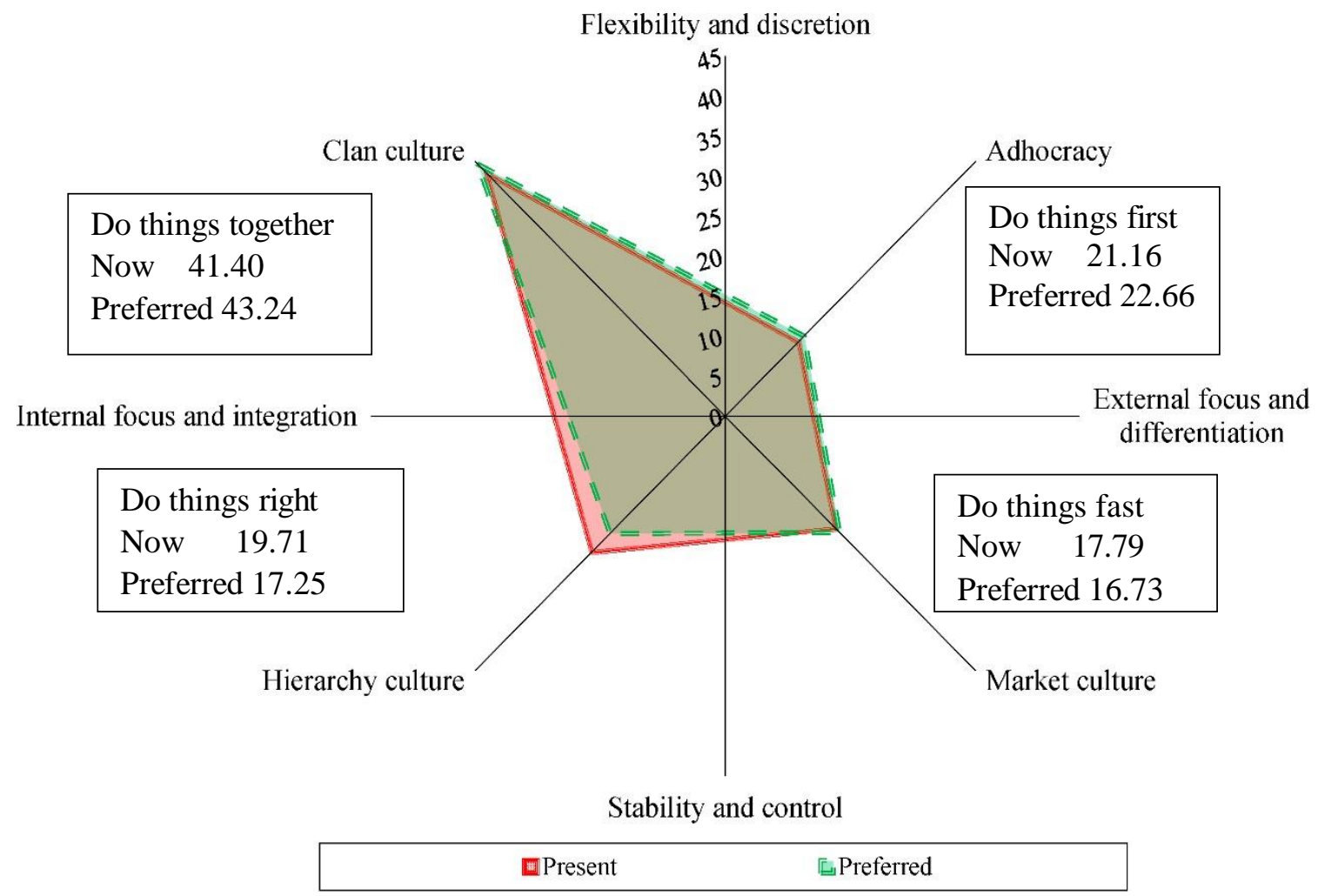

The results from Figure 1 indicate that on aggregate, clan culture was rated highest as very similar in both the Now (Mean = 41.40) and Preferred (Mean =43.24) by the participants in the current study. This was followed by adhocracy (Mean $=21.16$, and 22.66), hierarchical $($ Mean $=$ 19.71 and 17.25), and market culture (Mean = 17.79 and 16.73) now and preferred respectively. The results show that, Clan (Collaborate or doing thing together) culture was the dominant organization culture and also the preferred culture type among the sample. This implied that participants see themselves first as members of a family where people do things together for the overall good of the organization. The results further indicate that, the organizational culture 
among the sample was positioned between internal focus and integration and flexibility and discretion. This means that in the current study, participants presently practice collaboration and create and also preferred these culture types in their hospitality industry in the future. The findings reflect both the nature of religious congregations which are essentially family like and hospitality industry which requires flexibility and discretion in its management approaches. However, market culture been the least culture type among the sample has far- reaching implications for the ability of these hospitality centers to compete and grow in the highly competitive hospitality and tourism industry in the post COVID-19 era.

Next, the current study computed the score of the participants on Customer Satisfaction scale. The scoring for customer satisfaction from 1 strongly disliked to 5 strongly like and the frequency and percentage was computed. The highest possible mean score was 5 and the lowest was 1 . A mean score of 5 meant a very high level of satisfaction with their services, while a mean score of 1 meant customers were very dissatisfied with the services. The results of the descriptive statistics and Chi square analysis of the participants score on customer satisfaction are summarized in frequency, percentage, and significance and presented in Table 2. 
International Journal of Social Science and Economic Research

ISSN: 2455-8834

Volume:05, Issue:11 "November 2020"

\section{Table 2}

Chi- Square Output on Customer Satisfaction among the Participants $(n=158)$

\begin{tabular}{|c|c|c|c|c|c|c|c|c|}
\hline \multirow[t]{2}{*}{ Statements } & SDL & $\mathbf{D}$ & $\mathbf{N}$ & $\mathbf{L}$ & SL & \multirow[t]{2}{*}{ Value } & \multirow[t]{2}{*}{ df } & \multirow[t]{2}{*}{ sig } \\
\hline & F $\%$ & F $\%$ & F $\%$ & $\mathrm{~F} \quad \%$ & $\mathrm{~F} \quad \%$ & & & \\
\hline How would you rate staff appearance on duty & & & $7(4.4)$ & $73(46.2)$ & $78(49.4)$ & $3.717^{\mathrm{a}}$ & 4 & .446 \\
\hline Donum Dei & & & $3(1.9)$ & $30(19.0)$ & $44(27.8)$ & & & \\
\hline Passionist & & & $2(1.3)$ & $20(12.7)$ & $15(9.5)$ & & & \\
\hline $\begin{array}{lc} & \text { Chemi Chemi }\end{array}$ & & & $2(1.3)$ & $23(14.6)$ & $19(12.0)$ & & & \\
\hline How would you rate the staff's communication skill & & & $12(7.6)$ & $71(44.9)$ & $74(46.8)$ & $2.394^{\mathrm{a}}$ & 6 & .880 \\
\hline Donum Dei & & & $4(2.5)$ & $36(22.8)$ & $36(22.8)$ & & & \\
\hline Passionist & & & $4(2.5)$ & $16(10.1)$ & $17(10.8)$ & & & \\
\hline $\begin{array}{ll}\text { Chemi Chemi }\end{array}$ & & & $4(2.5)$ & $19(12.0)$ & $21(13.3)$ & & & \\
\hline $\begin{array}{l}\text { How would you rate staff's courteousness and } \\
\text { efficiency }\end{array}$ & & & $7(4.4)$ & 71(44.9) & $80(50.6)$ & $12.313^{\mathrm{a}}$ & 4 & .015 \\
\hline Donum Dei & & & $3(1.9)$ & $25(15.8)$ & $49(31.0)$ & & & \\
\hline Passionist & & & $2(1.3)$ & $24(15.2)$ & $11(7.0)$ & & & \\
\hline Chemi Chemi & & & $2(1.3)$ & $22(13.9)$ & $20(12.7)$ & & & \\
\hline $\begin{array}{l}\text { How would you rate staff's willingness to assist } \\
\text { guests at all times }\end{array}$ & & & $8(5.1)$ & $61(38.6)$ & $89(56.3)$ & $2.550^{\mathrm{a}}$ & 4 & .636 \\
\hline Donum Dei & & & $4(2.5)$ & $25(15.8)$ & $48(30.4)$ & & & \\
\hline Passionist & & & $2(1.3)$ & $17(10.8)$ & $18(11.4)$ & & & \\
\hline Chemi Chemi & & & $2(1.3)$ & $19(12.0)$ & $23(14.6)$ & & & \\
\hline $\begin{array}{l}\text { Indicate your view concerning the location of this } \\
\text { hospitality centre }\end{array}$ & & $\mathbf{1}(\mathbf{0 . 6})$ & $16(10.1)$ & 49(31.0) & 92(58.2) & $16.259^{\mathrm{a}}$ & 6 & .012 \\
\hline Donum Dei & & & $10(6.3)$ & $20(12.7)$ & $47(29.7)$ & & & \\
\hline Passionist & & & $3(1.9)$ & $20(12.7)$ & $14(8.9)$ & & & \\
\hline Chemi Chemi & & $1(0.6)$ & $3(1.9)$ & $9(5.7)$ & $31(19.6)$ & & & \\
\hline $\begin{array}{l}\text { Indicate your view as regard the internet, } \\
\text { transportation, and airtime }\end{array}$ & $1(0.6)$ & $4(2.5)$ & $38(24.1)$ & $57(36.1)$ & $58(36.7)$ & $27.258^{\mathrm{a}}$ & 8 & .001 \\
\hline
\end{tabular}


International Journal of Social Science and Economic Research

ISSN: 2455-8834

Volume:05, Issue:11 "November 2020"

\begin{tabular}{|r|c|c|c|c|c|c|}
\hline Donum Dei & $1(0.6)$ & $2(1.3)$ & $13(8.9)$ & $31(19.6)$ & $29(18.4)$ & \\
\hline Passionist & & $2(1.3)$ & $19(12.0)$ & $10(6.3)$ & $6(3.8)$ \\
\hline Chemi Chemi & & & $5(3.2)$ & $16(10.1)$ & $23(14.6)$ & \\
\hline
\end{tabular}

\begin{tabular}{|c|c|c|c|c|c|c|c|c|}
\hline \multicolumn{9}{|c|}{ Organizational Culture and Customer Satisfaction Cont'd. } \\
\hline \multirow[t]{2}{*}{ Statements } & SDL & $\mathbf{D}$ & $\mathbf{N}$ & $\mathbf{L}$ & SL & \multirow[t]{2}{*}{ Value } & \multirow[t]{2}{*}{ df } & \multirow[t]{2}{*}{ sig } \\
\hline & F $\%$ & F $\%$ & $\mathbf{F} \quad \%$ & F $\%$ & $\mathbf{F} \quad \%$ & & & \\
\hline $\begin{array}{l}\text { Indicate your view concerning the cost and varieties } \\
\text { of meals offered here }\end{array}$ & & $3(1.9)$ & $18(11.4)$ & $75(47.5)$ & $62(39.2)$ & $10.432^{\mathrm{a}}$ & 6 & .108 \\
\hline Donum Dei & & $1(0.6)$ & 11(7.0) & $27(17.1)$ & $38(24.1)$ & & & \\
\hline Passionist & & $1(0.6)$ & $3(1.9)$ & $21(13.3)$ & $12(7.6)$ & & & \\
\hline Chemi Chemi & & $1(0.6)$ & $4(2.5)$ & $27(17.1)$ & 12(7.6) & & & \\
\hline $\begin{array}{l}\text { Indicate your view in respect of the food service } \\
\text { system and the taste of food offered here }\end{array}$ & & & $14(8.9)$ & $67(42.4)$ & $77(48.7)$ & $23.142^{\mathrm{a}}$ & 4 & .000 \\
\hline Donum Dei & & & $4(2.5)$ & $21(13.3)$ & $52(32.9)$ & & & \\
\hline Passionist & & & $3(1.9)$ & $23(14.6)$ & $11(7.0)$ & & & \\
\hline $\begin{array}{ll}\text { Chemi Chemi } \\
\end{array}$ & & & $7(4.4)$ & $23(14.6)$ & $14(8.9)$ & & & \\
\hline $\begin{array}{l}\text { Indicate your level of likeness of how well customers } \\
\text { are informed about the terms of contract }\end{array}$ & $2(1.3)$ & & $28(17.7)$ & $76(48.1)$ & $52(32.9)$ & $9.882^{\mathrm{a}}$ & 6 & .130 \\
\hline Donum Dei & $2(1.3)$ & & 14(8.9) & $35(22.2)$ & $26(16.5)$ & & & \\
\hline Passionist & & & $11(7.0)$ & $15(9.5)$ & $11(7.0)$ & & & \\
\hline $\begin{array}{lc}\text { Chemi Chemi } \\
\end{array}$ & & & $3(1.9)$ & $26(16.5)$ & $15(19.5)$ & & & \\
\hline $\begin{array}{l}\text { Indicate your level of likeness for how well } \\
\text { customers complaints are been addressed }\end{array}$ & & $4(2.5)$ & 23(14.6) & $66(41.8)$ & $65(41.1)$ & $9.847^{\mathrm{a}}$ & 6 & .131 \\
\hline $\begin{array}{ll} & \text { Donum Dei }\end{array}$ & & $4(2.5)$ & $12(7.6)$ & $27(17.1)$ & $34(21.5)$ & & & \\
\hline Passionist & & & $8(5.1)$ & $16(10.1)$ & $13(8.2)$ & & & \\
\hline
\end{tabular}


International Journal of Social Science and Economic Research

ISSN: 2455-8834

Volume:05, Issue:11 "November 2020"

\begin{tabular}{|c|c|c|c|c|c|c|}
\hline Chemi Chemi & $3(1.9)$ & $23(14.6)$ & $18(11.4)$ & & & \\
\hline $\begin{array}{l}\text { Indicate your likeness for how well customers get } \\
\text { value for their money }\end{array}$ & $16(10.1)$ & $76(48.1)$ & $66(41.8)$ & $6.661^{\mathrm{a}}$ & 4 & .155 \\
\hline Donum Dei & $10(6.3)$ & $31(19.6)$ & $36(22.8)$ & & & \\
\hline Passionist & $3(1.9)$ & $17(10.8)$ & $17(10.8)$ & & & \\
\hline Chemi Chemi & $3(1.9)$ & $28(17.7)$ & $13(8.2)$ & & & \\
\hline $\begin{array}{l}\text { Indicate your likeness for the overall customer } \\
\text { service delivery here }\end{array}$ & $3(1.9)$ & $71(44.9)$ & $84(53.2)$ & $21.200^{\mathrm{a}}$ & 4 & .000 \\
\hline Donum Dei & $1(0.6)$ & $22(13.9)$ & $54(34.2)$ & & & \\
\hline Passionist & & $20(12.7)$ & $17(10.8)$ & & & \\
\hline Chemi Chemi & $2(1.3)$ & $29(18.4)$ & $13(8.2)$ & & & \\
\hline
\end{tabular}




\section{International Journal of Social Science and Economic Research}

ISSN: $2455-8834$

Volume:05, Issue:11 "November 2020"

The results from Table 2 indicate the customer satisfaction across the 12 -item scale of customer satisfaction. The descriptive statistics indicate a high score on customer satisfaction among the participants. Further, the Chi square analysis of the significant value of the observed differences in the descriptive statistics among the participants indicated a significant association between organizational culture and customer satisfaction. This was indicated in five items as follows: staff's courteousness and efficiency $X^{2}(4)=12.313, p<.015$, the location of the hospitality centre $X^{2}(6)=16.259, p<.012$, the internet, transportation, and airtime with $X^{2}(8)=27.258, p$ $<.001$, the food service system and the taste of food offered $X^{2}(4)=23.142, p<.000$, and likeness for the overall customer service delivery here with $X^{2}(4)=21.200, p<.000$. The results implied that clan culture has significant effect on customer satisfaction. Further, the level of customer satisfaction in all the congregations was high but more among Congregation 1 participants. This could be explained by the fact that this was the only congregation which had hospitality as a charism among the sample. Thus, the null hypothesis of the current study was rejected and the alternate hypothesis which states that the culture of an organization has significant effect on customer satisfaction among hospitality industry in religious congregations in Karen, Nairobi was accepted.

\section{DISCUSSION}

The findings from this study showed that clan culture was the dominant now and preferred culture among the sample. That adhocracy, hierarchical and market culture were second third and fourth now and preferred organizational culture respectively. This positively affects customer satisfaction among the participants. Findings are consistent with Al-Otaib, Yusof, and Wanlsmail (2019) who indicated that in Saudi Arabia, the culture of organization had a strong effect on the satisfaction of students, and that all the four components of organizational culture significantly influenced the satisfaction of students. The findings in the current study again resonate with Islam, Kassim, Ali, and Sadiq (2014) who with a Malaysian sample showed that organizational culture directly influence the satisfaction of customer and indirectly influences the commitment of staff. This indicates that, in different sectors and with varied samples, organizational culture positively affects customer satisfaction. Moreover, the findings revealed that some kinds of organizations may necessarily have similar organizational culture even when not completely the same. This was the case in the present study where those with hospitality as a charism and without charism in hospitality had the same organizational culture type.

Furthermore, findings on organizational culture and customer satisfaction in the current study have far-reaching implications for the industry. This is consistent with Dikmen (2017) that customer satisfaction is related to customer loyalty, repurchase intention of customers, and the overall performance of organizations. Thus, findings in the current study implied that with high 


\section{International Journal of Social Science and Economic Research}

ISSN: $2455-8834$

Volume:05, Issue:11 "November 2020"

level of customer satisfaction among the sample, the hospitality Centre operated by religious congregations will directly promote the loyalty of their customers, continued patronage, improved performance, and growth. However, the demographic characteristics of the customer participants indicated that most of the customers in selected hospitality Centre were Christians (religious men and women). This could have a negative impact on the overall growth and profitability rate of these hospitality industries due to its restricted customer base.

Lastly, the finding of the lowest mean in market and hierarchical culture in both now and preferred dimensions of organizational culture among the sample indicated a very important area these hospitality industries need to elevate to enhance their general performance. This means that in a very competitive industry such as hospitality, the selected congregation need to raise their repertoire of services offered to enhance their competitive edge and thus ensured better performance.

\section{CONCLUSIONS AND RECOMMENDATIONS}

The key conclusion from the first research objective is that organizational culture and hospitality as a charism is strongly related to customer satisfaction among the sample. Thus, congregations who operate hospitality industry as part of their charism promote better satisfaction for their customers as against those religious congregations who operate hospitality Centre without a charism in hospitality. Generally, the study concludes that organizational culture plays a significant role in social transformation among hospitality industry run by religious congregations. This was specifically true in relation to high levels of customer satisfaction among the sample. Thus, some salient general conclusions include that, to enhance better customer satisfaction, congregations who operate hospitality industry without such charism need some training in hospitality. The identified picture of the organizational culture in this study indicated that the sampled hospitality industry is low in hierarchical and market culture in both now and preferred dimensions. This may have long-term implications on their ability to remain in a highly competitive business such as hospitality without improving their competitive edge.

The study made recommendations in two broad areas of practice and policy formulations. On the area of practice, this study made recommendations to five stakeholders who would be central to the implementation of the findings of this study. On the aspect of practice, Superiors of religious congregations could use the findings to investigate the dominant and preferred organizational culture type to enhance customer satisfaction and their overall performance. This will help them to understand their current status, and what they need to do differently to achieve a better impact in their communities. In the same vein, Management of ecclesiastical and corporate organizations need to examine the dominant and preferred organizational culture in their 


\section{International Journal of Social Science and Economic Research}

ISSN: $2455-8834$

Volume:05, Issue:11 "November 2020"

respective organizations, and use such knowledge to improve the development of their employees and the general performance of their organizations. Again, hospitality industry operated by religious congregations need to understand their culture type, to help position them for more effectiveness, growth and profitability through making adjustments in areas which need changing or improvement as determined by their organizational culture quadrants. Further, Public and private investors in hospitality industry need to establish their organizational culture and how it affects their performance generally. On the area of policy formulation, the study recommends a multi-approach to reposition hospitality industry for better performance. The findings that market culture was the least dominant and preferred culture type in a competitive industry like hospitality means that, there is need to evaluate the policy informing the establishment of hospitality Centre in religious congregations to position them for better performance in the post COVID-19 economy. Further, findings of this study should help congregations whose charism is not hospitality to improve their operation to enhance their customer satisfaction. These organizations must not only invest in hospitality, but need to train their members in the act of hospitality to position them for better service delivery which will promote better customer satisfaction and their overall performance. Lastly, the COVID-19 pandemic has impacted negatively on hospitality and tourism sector during this year resulting in some hospitality centre going insolvent. The study recommends the intervention of Government in the form of tax exemption to hospitality industry. If well implemented, this will help the hospitality industry to survive the economic crunch caused by the COVID-19, as well as to reposition the hospitality industry for better performance in the post COVID-19 economy.

\section{REFERENCES}

Adeola, O., \& Ezenwafor, K. (2016). The hospitality business in Nigeria: Issues, challenges and opportunities. Journal of Worldwide Hospitality and Tourism, 8(2), 182-194. https://doi.org/10.1108WHATT-11-2015-0053.

Al-Otaib, S.A., Yusof, S.M., \& WanIsmail, W.K . (2019). The Influence of Organizational Culture on Students' Satisfaction in Saudi Arabia. Proceedings of the International Conference on Industrial Engineering and Operations Management Bang, March 5-7 (pp. 2195-2203). Bangkok: IEOM Society International.

Babalola, W.A., \& Oluwatoyin, O. (2014). Direction for the future of tourism, hospitality and events management education in Nigeria. Babalola, W.A., \& Oluwatoyin, O. (2014). Direction for the future of touJournal of Tourism, Hospitality and Sport, 2, 39-52.

Cameron. K.S., \& Quinn, R.E. (2011). Diagnosing and changing organizational culture: Based on the competing value framework ( $3^{\text {rd }}$ ed.). San Francisco: Jossey-Bass. 


\section{International Journal of Social Science and Economic Research}

ISSN: $2455-8834$

Volume:05, Issue:11 "November 2020"

Christian. (2015). The hospitality sector: Contribution to GDP and employment. . London: http://www.aalep.eu/hospitality-sector-contribution-gdp-and-employment.

de Bastion, G., Schodder, R., Stroebel-Haft, Z., \& Mazimhaka, J. (2019). Digitalization and tourism in Rwanda: Market analysis. Deutsche Gesellschaft für Internationale Zusammenarbeit (GIZ) GmbH.

Dikmen, F. (2017). The role of service culture in hospitality industry. International Journal of Business and Social Science, 8(5), 85-98.

Ekpenyong, N.S., \& Ekpenyong, A.S. (2016). Organizational culture and its impact on employee performance and job satisfaction: A case study of Niger Delta University, Amassoma . Higher Education of Social Science, 11(5), 36-45. Doi: 10.3968/8876.

Government of Kenya (2013). National tourism strategy (2013-2018). Nairobi, GOK. Government of Kenya (2018). Economic tourism reports (2018). Nairobi, GOK.

Grönroos, C. (2007). Service management and marketing: Customer management in service competition (3rd ed.). New York: John Wiley \& Sons.

Irfan, M., Shamsudin, M.F., \& Hadi, N.U. (2016). How important is customer satisfaction? Quantitative evidence from Mobile Telecommunication market . International Journal of Business and Management, 11(6), 57-69. Doi:10.5539/ijbm.v11n6p57.

Islam, T., Kassim, N.A., Ali, G., \& Sadiq, M. (2014). Organizational learning culture and customer satisfaction: The mediating role of normative commitment. The Learning Organization, 21(6), 392-404. https://doi.org/10.1108/TLO-07-2014-0040 .

Kamau, P.M., \& Wanyoike, R.W. (2018). Corporate culture and organizational performance: A case of Mayfair Casino, Nairobi city County, Kenya. Global Journal of Commerce and Management Perspective, 8(1), 8-17. https://doi.org/10.24105/gjcmp.2019.8.2.

Kendall, S. (2007). Customer service from the customer's perspective. In L. Fogli (Ed.), Customer service delivery: Research and best practices. J-B SIOP Professional Practice Series 20, (pp. 43-65). New York: Wiley and Sons.

Kruja, D., Ha, H., Drishti, E., \& Oelfke, T. (2016). Empowerment in the hospitality industry in the United States. Journal of Hospitality Marketing and Management, 25(1) 25-48. https://doi.org/10.1080/19368623.2015.976696. 


\section{International Journal of Social Science and Economic Research}

ISSN: $2455-8834$

Volume:05, Issue:11 "November 2020"

Lianping, R. (2019). Budget hotels in China: Recent development, changes, and challenges. In J. Zhao (Ed.), Advances in Hospitality and Tourism: The Hospitality and Tourism industry in China. New growth, trends, and developments (pp. 1-14). New Jersey: Appel Academic Press Inc.

Lin, J.S.C., \& Wu, C.Y. (2011). The role of expected future use in relationship-based retention. Managing Service Quality, 21(5), 535-551.

Malik, E., \& Ghaffor, M. (2012). Impact of brand image, service quality and price on customer satisfaction in Pakistan telecommunication sector. International Journal of Business ans Social Science, 3(2), 123-134.

Mensah, I., \& Mensah, R.D . (2018). Effects of service quality and customer satisfaction on repurchase intention in restaurants on University of Cape Coast campus. Journal of Tourism, Heritage and Services Marketing, 4(1), 27-36. Doi: 10.5281/zenodo.124754.

Naranjo-Valencia, J.C., Jimenez-Jimenez, D.J., \& Sanz-Valle, R. (2015). Studying the links between organizaional culture, innovation, and performance in Spanish companies. Revista Latinoamericana de Psicologia, 48(1), 30-41. Doi: 10.1016/j.rip.2015.09.009.

Njegus, A. (2014). Introduction to e-Tourism. Presentation. Belgrad. Kigali: Retrieved from https://www.slideshare.net/AngelinaNjegus/lesson-01-introduction-to-e-tourism42835161).

Okan, Z.A., \& Pınar Acar Okan, P.A . (2014). Organizational Culture Types and Their Effects on Organizational Performance in Turkish Hospitals. Emerging Markets Journal, 3(3), 17-31. DOI 10.5195/emaj.2014.47.

Ondieki, E.B., \& Kung'u, S.K. (2013). Hospitality employment: policies and practices in hotels in Kenya. Journal of Tourism and Hospitality Management, 1(1), 32-37.

Naranjo-Valencia, J.C., Jimenez-Jimenez, D.J., \& Sanz-Valle, R. (2015). Studying the links between organizaional culture, innovation, and performance in Spanish companies. Revista Latinoamericana de Psicologia, 48(1), 30-41. https://doi.org/10.1016/j.rip.2015.09.009.

Owino, O.J., \& Kibera, F. (2019). Organizational culture and performance: Evidence from Microfinance institutions in Kenya. Sage Journal, 9(1), 1-11, https://doi.org/ $10.1177 / 2158244019835934$. 
International Journal of Social Science and Economic Research

ISSN: 2455-8834

Volume:05, Issue:11 "November 2020"

Quinn, R. E., \& Spreitzer, G. M. (1991). The Psychometrics of the Competing Values Culture Instrument and an Analysis of the Impact of Organizational Culture on Quality of Life. " In R. W. Woodman, \& W.A. Pasmore (Eds.), Research in Organizational Change and Development (pp. 24-55). Greenwich, Conn: JAI Press.

Radwan, H., \& Radwan, I. (2017). Managing hotels during economic challenges: A case study on hotels in Sharm El-Sheikh and Hurghada, Egypt. Journal of Tourism and Hospitality Management, 5(2), 84-100. Doi: 10.15640/jthm.v5n2a9.

Rosa, N.M.B., \& Hastings, S.O. (2016). Managers making sense of millennials: Perceptions of a generational cohort. Qualitative Research Reports in Communication, 17(1), 52-59. https://doi.org/10.1080/17459435.2015.1088895.

SelectUSA. (2019, November 5). Travel, tourism and hospitality spotlight: The travel tourism and hospitality in the United State. . Retrieved from Retreived from https://www.selectusa.gov/travel-tourism-and-hospitality-industry-united-states: https://www.selectusa.gov

Sharma, A., \& Singh, S. (2017). Impact of organizational culture on employee commitment: A comparative study of public and private sector telecom companies in India. International Journal of engineering Technology Science and Research, 4(12).721727.

World Economic Forum. (2015). The travel and tourism competitiveness report 2015. Geneva: World Economic Forum (WEF).

World Travel and Tourism Council. (2017). The impacts of travel and tourism on jobs and the economy. London: WTTC.

World Travel and Tourism Council. (2018). The impacts of travel and tourism on jobs and the economy. London: WTTC. 